\title{
Research into limits of gas-fired burners flame stabilization in the flue gas recirculation
}

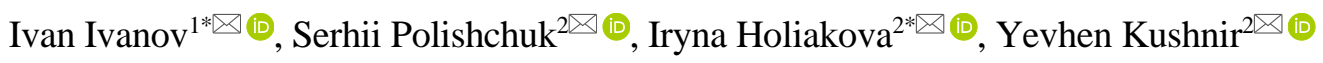 \\ ${ }^{1}$ Metallurgical Academy of Ukraine, Dnipro, 49005, Ukraine \\ ${ }^{2}$ Prydniprovsk State Academy of Civil Engineering and Architecture, Dnipro, 49600, Ukraine \\ *Corresponding author: e-mail holiakova.ira@pgasa.dp.ua, tel. +380688962299
}

\begin{abstract}
Purpose. Determining the flue gas recirculation effect on the verge of the gas-fired burners flame stabilization based on experimental industrial research.

Methods. The studies were conducted on a circular heating furnace with a diameter of $30 \mathrm{~m}$ of the Interpipe NTRP wheelrolling workshop. The furnace for blanks heating to $625 \pm 25^{\circ} \mathrm{C}$ with their isothermal holding has 5 zones with an adjustable and systematic supply of natural gas. To increase the thermal performance efficiency, the furnace has been equipped with an external exhaust gas recirculation system. When assessing the burners forcing ability of the after their ignition, the gas consumption, as well as recycled gas consumption was increased gradually in a predetermined ratio. Therewith, gas consumption was determined at the time of the flame-out, which was recorded visually.

Findings. Based on a comprehensive analysis, the factors have been revealed, which affect the sustainability of the burner operating modes when exhaust flue gases are fed into the combustion zone. It is shown that the most rational for analyzing the recirculation influence on gas combustion stability is the use of criterion empirical models that take into account the complex of physical-chemical characteristics of the reagents, parameters of the combustion mode, gas-dynamic and design burner peculiarities. A criterion model has been obtained for the loss of a diffusion flame in combined "pipe-in-pipe" type burners when burning gas fuel in a medium of recycle flue gases with a temperature of $140-200^{\circ} \mathrm{C}$ and an oxygen composition of 15.4-19.6\% in them. Dependences have been determined for assessing the expansion of combustion stability limits with a change in the coefficient of the oxidising agent consumption, its temperature, and the recirculation ratio.
\end{abstract}

Originality. New computational models have been obtained for assessing the limits of the flame stabilization of straightflow gas burners during flue gas recirculation. The ratios have also been found of the recirculation ratio and the oxidising agents temperatures, that provide the conditions of their identical work for the flame-out and flame backflash when replacing the air with recycled gas for fuel combustion.

Practical implications. The results make it possible to make a reasonable choice of burners and combustion standard parameters that ensure the safe unit operation during flue gas recirculation.

Keywords: combustion, fuel, recirculation, stability, flame-out, flame backflash, burner, model

\section{Introduction}

Exhaust gas recirculation in technological and generating units is an effective means of improving the technical and economic indicators of their work [1], [2]. Through reducing the temperature gradient in the working volume during recirculation, the deviation of the materials temperature can be reduced from the set value to the values required by the technology and their quality heating can be ensured [3]. Moreover, with an increase in the volumes of heating gases, there is an intensification of convection heat transfer and a reduction in energy consumption by $20-30 \%$ [4].

Thermal generating units consuming fossil fuels (coal, wood, oil, gas, etc.) are a powerful source of nitrogen oxide emissions into the atmosphere; they account for over $95 \%$ of the total amount of $\mathrm{NO}_{x}$ industrial emissions [5], [5]. Exhaust gas recirculation is a radical means to reduce the nitrogen oxides formation during fuel combustion [7], [8].

When returning exhaust cooled flue gases to the combustion zone, the maximum temperature in it is reduced due to the removal of heat for their heating. Also, there is a retardation of chain reactions in $\mathrm{NO}_{x}$ formation due to the presence of inert gases and a decrease in the reacting substances concentration. The complex action of these factors causes a reduction in $\mathrm{NO}_{x}$ emission [9], [10].

Flue gas utilization is widely used when changing to nonwaste production using alternative coal mining technologies underground coal gasification [11], [12], in the decomposition of gas hydrate deposits [13], and also for carbon capture 
and storage [14], [15]. With this technology, flue gases, consisting mainly of carbon dioxide $\left(\mathrm{CO}_{2}\right)$, nitrogen oxides $\left(\mathrm{NO}_{x}\right)$ and sulfur $\left(\mathrm{SO}_{x}\right)$, from the power generating unit are fed back to the underground gas generator and distributed along the reaction channel length [16].

The flue gases elimination during underground coal gasification is possible with recirculation according to the never-ending circle principle [17]. When interacting with hot carbon, carbon dioxide is transformed into carbon monoxide gas $\mathrm{CO}$ with the heat absorption [18], [19]. Simultaneously, at high gasification temperatures, $\mathrm{CO}_{2}$ dissociation (decomposition) also occurs. Sulfur and nitrogen oxides are also decomposed simultaneously to a non-toxic state. Environmentally harmful chemical compounds, arsenic, and other radioactive elements also remain in the collapsed rocks. In this case, in the presence of moisture (coal is always wet), the sulfur and nitrogen oxides are destroyed to a non-toxic state. Other compounds, harmful to the biosphere (arsenic, strontium, thorium, uranium, etc.), remain in the gassedout zone [20]-[22] and can be used as backfilling material [23].

Traditionally, the greatest recirculation effect is achieved by completely flue gases pre-mixing with air and feeding this prepared mixture into the fuel active combustion zone. In this sense, it is expedient to introduce combustion products into the air ducts in front of the burners. According to calculations [24], with a recirculation ratio $R=1.1$, the possible $\mathrm{NO}_{x}$ emission can be reduced by $23-30 \%$; with $R=1.2$ by $39-50 \%$; with $R=1.3$ by $50-63 \%$; with $R=1.5, \mathrm{NO}_{x}$ emission can be reduced by 3-4 times. An experience evidences that even when working with recirculation ratios of $20-30 \%$, it is possible to reduce the nitrogen oxides consumption by 50-60\% [25]-[27].

Combustion products recirculation in the tail vacuum chambers of the sinter machines allows a $60-70 \%$ reduction in the composition of dioxins and furans in the exhaust gases of the iron ore agglomerating [28], [29]. These superecotoxicants, together with flue gases, enter the combustion zone and at high temperatures are almost completely decomposed.

At the same time, the organization of exhaust gas recirculation does not normally require significant capital and operating costs, which is important in a difficult economic situation in the country. A difficult problem associated with the exhaust gas recirculation, when using in technological and generating units, is to ensure the stable burners operation. The recycled gas supply to the combustion zone leads to an increase in the amount of inert components in the flame front and enhancing heat removal from it. This complicates the combustion process, can lead to a disturbance of the flame stability and flame attenuation, and with a high ballast content - to the non-combustible mixtures formation [29]-[32].

Ensuring the stable combustion is an essential condition for the safe operation of thermal generating units. The choice of insufficiently substantiated standard parameters that do not take into account the peculiarities of the fuel combustion process in the recycled gas medium can create difficulties in ensuring the unit operability, calling into question the efficiency and expediency of recirculation. The flame stability is determined by the ratio of the flame propagation velocity $U$ and the gas-air mixture intake velocity to the place of its combustion $\omega$ (Fig. 1).

In stationary mode, a dynamic equilibrium is set between the tendency of the flame to move towards the combustible mixture movement and the tendency of the flow to move the flame away from the burner slot. In the initial area, the flame front stability is ensured by full compensation of $U$ value with the flow velocity $\omega$, and in other sections it is compensated by its normal component $\omega \cdot \cos \varphi$ [33], [34].

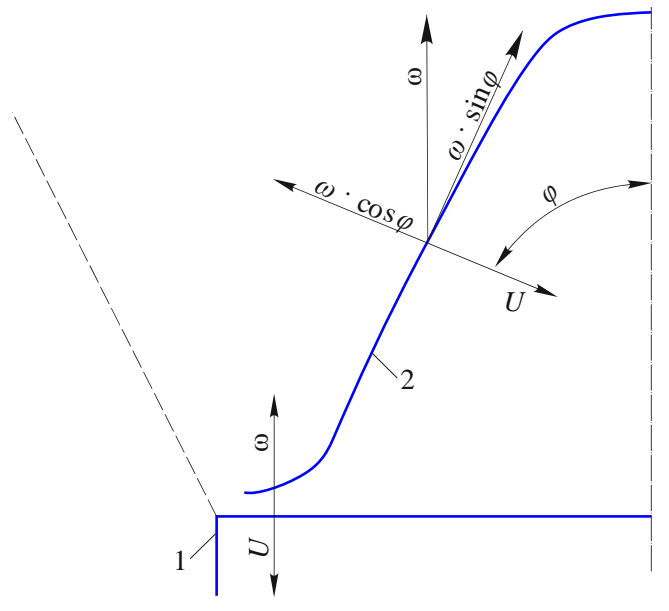

Figure 1. Scheme of the gas-air mixture flame front: 1 - mixture outflow channel; 2 - flame front

If the mixture efflux velocity exceeds the flame propagation velocity, the stability of the flame is disturbed, it is separated from the burner top [35]. It is accompanied by an increase in the flame flickering, which leads to a flame-out and its attenuation (Fig. 2).

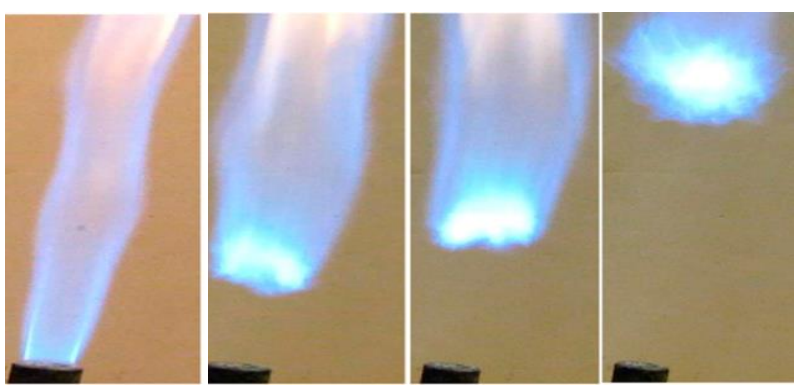

Figure 2. The process of a gas flame-out from a burner

Through the extinguished burner gas continues to enter; gas-air mixture is accumulated in the working volume and in gas ducts, which can lead to an explosion, destruction of the unit structure, and other serious consequences. This occurs most often in the course of the burners ignition or when they are turned off, and during operation - caused by an increase in gas pressure above the permissible, as well as a sharp increase in air supply, or the burner operation in the modes superlimiting compared to the passport ones [36].

If the $U$ value exceeds the velocity of fresh mixture approach to the flame front, a backflash of the flame is possible in the preliminary mixing burners: the flame is drawn into the burner and the mixture burns inside it. This causes the housing deformation due to overheating and burner failure. Sometimes a flame backflash is accompanied by a noise impact, the flame is extinguished and there is a gas contamination of the working volume and flue ducts through the idle burner.

Flame backflash is possible both as with improper ignition and turning off the burner, so with a rapid decrease in its performance. Flame backflash phenomenon is observed only in the preliminary mixing burners, and flame lift-off - in other types of burners [37].

Figure 3 shows the influence nature of the oxidising agent (air) $\alpha$ consumption coefficient on the limiting velocities of the gas-air mixture efflux from the burner $\omega$ [38]. The range between the areas of the flame backflash and the flame-out determines the limits to adjust the burner turndown. 


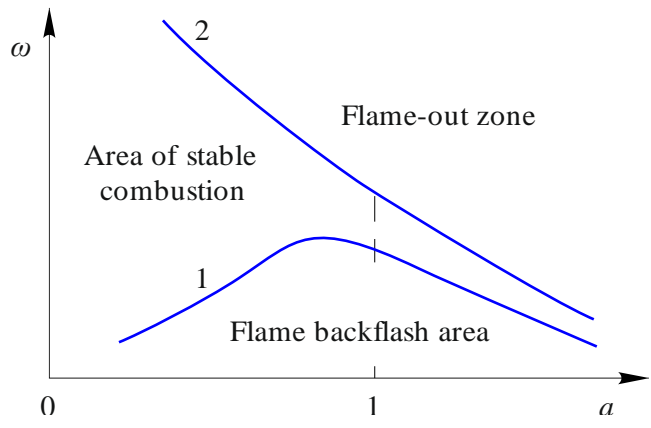

Figure 3. Limits of preliminary mixing burners stable operation: 1 - limit of the flame backflash; 2 -flame-out limit

The purpose of this paper is to determine the influence of flue gas recirculation on the verge of the gas-fired burners flame stabilization.

\section{Methods}

Theoretical models of combustion stability [39], [40], despite the complexity and multifactorial process nature, are only in qualitative agreement with experimental data [41]. Therefore, in practice, experimental data obtained from bench or industrial tests of burners with various designs are used to determine the flame stabilization limits [42].

Through processing data, the criterion dependences are obtained that take into account the influence of the physicalchemical properties of the reagents, the gas-dynamic and structural parameters of the burners on the flame stability, and are usually presented in the form:

$P e_{\omega}=b_{0} \cdot P e_{U}^{b 1} \cdot a^{b 2}$,

where:

$$
P e_{\omega}=\omega \cdot \frac{d}{a} \text { and } P e_{U}=U \cdot \frac{d}{a}-\text { the Peclet criteria for the }
$$

critical velocity $\omega$ of a flame-out or flame backflash, as well as the normal velocity of its propagation $U$;

$d$-characteristic burner dimension (nozzle diameter or fitting pipe);

$a$-temperature conductivity coefficient of the mixture of gas fuel and oxidising agent;

$b_{0}, b_{1}, b_{2},-$ empirically determined coefficient.

The studies were conducted on a circular heating furnace with a diameter of $30 \mathrm{~m}$ of the Interpipe NTRP wheel-rolling workshop. The furnace for blanks heating to $625 \pm 25^{\circ} \mathrm{C}$ with their isothermal holding has 5 zones with an adjustable and systematic supply of natural gas. To increase the thermal performance efficiency, the furnace has been equipped with an external exhaust gas recirculation system.

Exhaust flue gases with a temperature of $200-250^{\circ} \mathrm{C}$ are taken with a VM-15 fan, at the inlet they are diluted with air preheated to $70-80^{\circ} \mathrm{C}$ in the recuperator to a temperature of $200-210^{\circ} \mathrm{C}$ of fan thermal stability. The recycled gas is supplied to the existing air manifold of the furnace, disconnected by a plug from the recuperator.

The experiments were performed on the $1^{\text {st }}$ and $3^{\text {rd }}$ zones along the smoke way in the furnace, equipped with oil-gas burners with a gas nozzle diameter of $50 \times 46$ and $52 \times 46 \mathrm{~mm}$, respectively. For guaranteed gas afterburning during shortterm flame-outs during the experiments, a temperature of $800-820^{\circ} \mathrm{C}$ and an air consumption coefficient of 1.2-1.3 were maintained in the $4^{\text {th }}$ zone.
When assessing the forcing ability of the burners after their ignition, the gas consumption, as well as recycled gas consumption was increased gradually in a predetermined ratio. Therewith, the gas consumption was determined at the time of the flame-out, which was recorded visually. The limiting parameters of the combustion mode were assessed when the gas consumption was stabilized in the operating range and the recycled gas consumption was gradually increased until the flame-out.

In a previous experiment, the normality has been determined of the research data distribution and the need for a four-fold experiments repetition to ensure an error of not more than 5\%. At the main stage, 36 tests have been conducted to assess the limiting burners forcing and 24 tests to determine their characteristics of flame-out at operating gas consumptions. With that, recycled gas temperature was $140-200^{\circ} \mathrm{C}$, the oxygen composition in it was $15.4-19.6 \%$.

When forming a criterion model for the diffusion flame stability during gas fuel combustion, in recycled gas, a priori, the existence of a link was assumed between the gas efflux velocity $\omega$ during flame-out and the normal flame propagation velocity $U$ and the recycled gas consumption coefficient $\alpha$. These values were calculated by the formulas:

$$
\begin{aligned}
& \omega=\frac{4 q}{3600 \cdot \pi\left(d^{2}-d_{1}^{2}\right)} ; \\
& a=\frac{V}{q \cdot L_{0}} ; \\
& U=\frac{\sum_{i=1}^{n} P_{i} U_{i}}{\sum_{i=1}^{n} P_{i}}\left(1-0.01 N_{2}-0.012 C O_{2}\right) \cdot\left(\frac{T}{293}\right)^{1.75},
\end{aligned}
$$

where:

$q, V$-hourly consumption of gas and recycled gas at the time of flame-out;

$d, d_{1}$ - outer and inner burner gas nozzle diameter;

$L_{0}$ - theoretical air consumption for combustion of $1 \mathrm{~m}^{3}$ of gas;

$P_{i}, U_{i}$ - the composition of simple mixtures in complex one and the normal flame propagation velocity in simple mixtures;

$T, \mathrm{~N}_{2}, \mathrm{CO}_{2}$ - the absolute temperature of the stoichiometric mixture of gas and recycled gas, $\%$ of nitrogen and carbon dioxide in it, respectively.

The outer diameter $d$ of the burner gas nozzle is taken as a characteristic size, since during diffusion combustion, flame stability is determined by the zone at the periphery of the gas stream at the exit out of the nozzle, where the fuel reacts with an oxidising agent in a ratio close to stoichiometric. To assess the temperature conductivity coefficient of the stoichiometric mixture of gas and recycled gas $a$, reference data were used.

\section{Results and discussion}

Figure 4 presents the logarithmic dependences of the Peclet criterion for the flame-out velocity on this criterion for the normal flame propagation velocity at various values of the recycled gas consumption coefficient. 
(a)

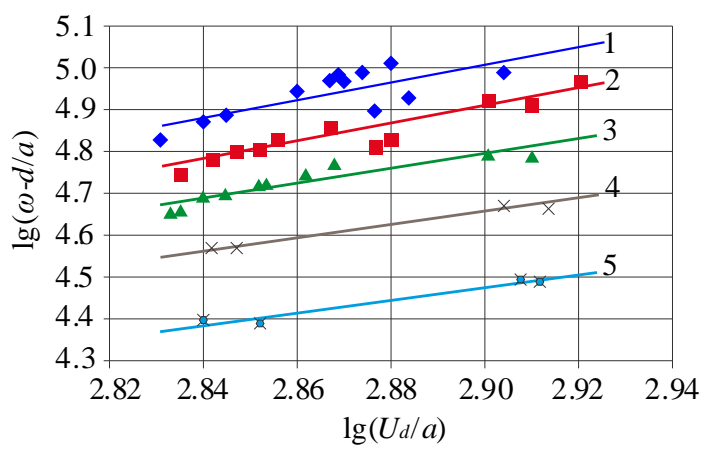

(b)

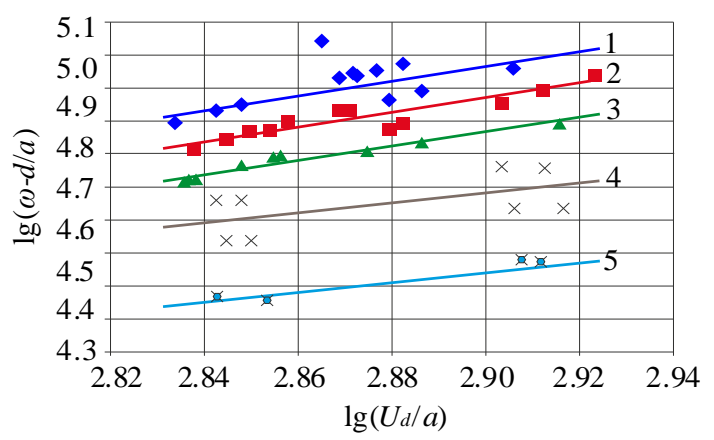

Figure 4. Experimental data processing on flame-out in burners with $d=52 \mathrm{~mm}($ a) and $d=50 \mathrm{~mm}(\mathrm{~b})$ to obtain a model $P e_{\omega}=f\left(P e_{U} ; \alpha\right):$ calculated lines of regression and experimental data $1 \bullet-\alpha=1.1-1.25 ; 2 \square-\alpha=1.25-1.4$; $3 \triangle-\alpha=1.4-1.55 ; 4 \times-\alpha=1.55-2.05 ; 5 \approx-\alpha=2.05-2.45$

Through experimental data approximation, the criterion model coefficients have been obtained $b_{0}=0.177 ; b_{1}=2.02$; $b_{2}=2$. Their significance is confirmed by the calculated values of the Student's test for them, which are almost an order of magnitude higher than the tabular value $t_{t}=1.988$ with a confidence probability of $95 \%$. The adequacy variance $S_{a v}=1.817$ is significantly less than the experimental error $S_{0}=4.406$. That is, the obtained model of the flame-out velocity during the natural gas combustion in recycled gas for combined oil-gas burners of "pipe-in-pipe" type is adequate. This allows using it to obtain reliable results and to implement them into practice when choosing standard combustion parameters, which ensure the safe thermal operation of thermal generating unit.

The values of $U$ and $a$ are determined by the combustible mixture temperature and the amount of ballast in it, that is, in the end, by the recirculation ratio $R$ and the recycled gas temperature $t_{p}$ with a stable gas composition and its temperature. Table 1 shows the calculated values of these parameters that correspond to the temperature range of the recycled gas and the oxygen composition in it during industrial burners tests.

Through these data approximation, the dependences have been obtained:

$U=0.408 \cdot \theta^{1.674} \cdot R^{-0.988}, \mathrm{~m} / \mathrm{s} ;$

$a=22.72 \cdot 10^{-6} \cdot \theta^{1.709} \cdot R^{-0.049}, \mathrm{~m}^{2} / \mathrm{s}$,

where:

$\theta=T_{p} / 273$-dimensionless absolute recycled gas temperature.
Table 1. Initial data to obtain dependences $U=f_{1}(R ; \theta) ; a=f_{2}(R ; \theta)$

\begin{tabular}{ccccc}
\hline No. & $t_{p},{ }^{\circ} \mathrm{C}$ & $R$ & $U, \mathrm{~m} / \mathrm{s}$ & $a \cdot 10^{6}, \mathrm{~m}^{2} / \mathrm{s}$ \\
\hline 1 & & 1.11 & 0.65 & 40.5 \\
2 & & 1.06 & 0.68 & 40.6 \\
3 & & 1.09 & 0.66 & 40.5 \\
4 & \multirow{2}{*}{140} & 1.12 & 0.65 & 40.5 \\
5 & & 1.08 & 0.67 & 40.6 \\
6 & & 1.09 & 0.67 & 40.5 \\
7 & & 1.10 & 0.66 & 40.5 \\
\hline 8 & & 1.16 & 0.67 & 43.9 \\
9 & & 1.18 & 0.66 & 43.8 \\
10 & & 1.21 & 0.65 & 43.8 \\
11 & \multirow{2}{*}{160} & 1.17 & 0.67 & 43.8 \\
12 & & 1.20 & 0.65 & 43.8 \\
13 & & 1.19 & 0.66 & 43.8 \\
14 & & 1.17 & 0.66 & 43.9 \\
\hline 15 & & 1.22 & 0.70 & 47.3 \\
16 & & 1.24 & 0.68 & 47.2 \\
17 & & 1.26 & 0.68 & 47.2 \\
18 & 180 & 1.22 & 0.69 & 47.2 \\
19 & & 1.25 & 0.68 & 47.2 \\
20 & & 1.23 & 0.69 & 47.2 \\
21 & & 1.20 & 0.70 & 47.3 \\
\hline 22 & & 1.27 & 0.72 & 50.7 \\
23 & & 1.29 & 0.71 & 50.6 \\
24 & & 1.31 & 0.70 & 50.6 \\
25 & 200 & 1.28 & 0.71 & 50.6 \\
26 & & 1.32 & 0.69 & 50.6 \\
27 & & 1.32 & 0.69 & 50.5 \\
28 & & 1.29 & 0.71 & 50.6 \\
\hline & & & &
\end{tabular}

Having substituted (5) and (6) into formula (1), taking into account the found values of the coefficients $b_{0}, b_{1}, b_{2}$ the expression can be obtained for the flame-out velocity in these burners during combustion in the recycled gas medium:

$\omega=1577.5 \cdot a^{-2} \cdot d^{1.02} \cdot \theta^{1.638} \cdot R^{-1.945}, \mathrm{~m} / \mathrm{s}$.

When burning with air for a burner with a gas nozzle diameter $d_{b}$, the flame-out velocity is:

$\omega_{b}=1577.5 \cdot a_{b}{ }^{-2} \cdot d_{b}^{1.02} \cdot \theta_{b}^{1.638}, \mathrm{~m} / \mathrm{s}$,

where:

$\alpha_{b}, \theta_{b}=T_{b} / 273-$ air consumption coefficient and its dimensionless absolute temperature.

Ratio of flame-out velocities with and without recirculation:

$\frac{\omega}{\omega_{b}}=\left(\frac{a}{a_{b}}\right)^{-2} \cdot\left(\frac{d}{d_{b}}\right)^{1.02} \cdot\left(\frac{\theta}{\theta_{b}}\right)^{1.638} \cdot R^{-1.945}$.

When transferring the unit to gas combustion in recycled gas instead of air without replacing the burners $\left(d=d_{b}\right)$ and changing the oxidising agent consumption $\left(\alpha=\alpha_{b}\right)$, we have:

$\frac{\omega}{\omega_{b}}=\left(\frac{\theta}{\theta_{b}}\right)^{1.638} \cdot R^{-1.945}$.

Hence it is clear that the provision of $\omega=\omega_{b}$ is possible provided:

$R=\left(\frac{\theta}{\theta_{b}}\right)^{0.84}$. 
With $R>\left(\theta / \theta_{b}\right)^{0.84}$, the conditions for flame stabilization in combined "pipe-in-pipe" type burners are worsened with the replacement of air by recycled gas, and with $R<\left(\theta / \theta_{b}\right)^{0.84}$, adjustable range of burners for gas consumption is expanded.

The consumption characteristic of the burner is unchanged with a recycled gas consumption coefficient:

$a=a_{b}\left(\frac{\theta}{\theta_{b}}\right)^{0.82} \cdot R^{-0.973}$,

and if this condition is unsatisfied, sustainable combustion can be organized by setting a burner with a gas nozzle diameter:

$d=d_{b} \cdot\left(\frac{a}{a_{b}}\right)^{1.961} \cdot\left(\frac{\theta}{\theta_{b}}\right)^{-1.665} \cdot R^{1.907}$

Figure 5 shows the dependences $R=f\left(\theta / \theta_{b}\right)$ with $d=d_{b}$ and different values of $a / a_{b}$ and $\omega / \omega_{b}$, which determine the adjusting ability of burners.

(a)

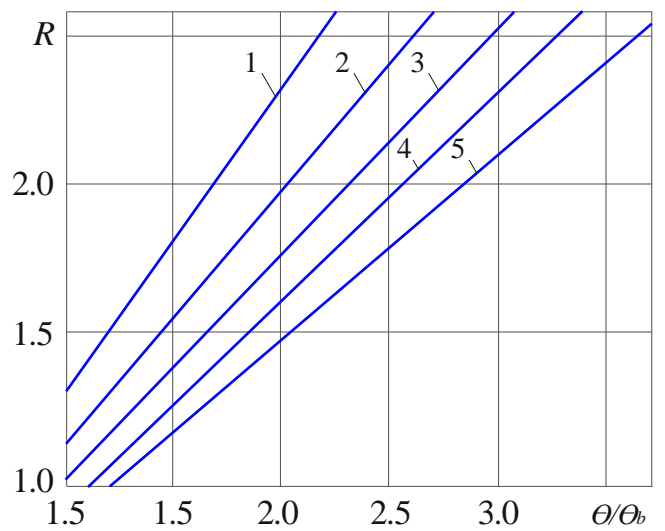

(b)

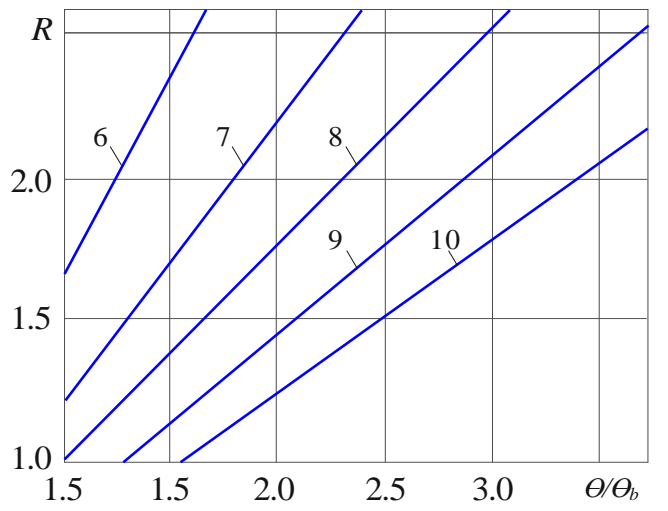

Figure 5. Recycled gas parameters influence on the verge of adjusting the combined "pipe-in-pipe" type burners

To assess the influence of the recycled gas parameters on the stable operation of other types of burners, the models were used for the flame-out velocity $\omega$ and flame backflash $\omega_{n}$, which are presented in [43], [44]:

- for injector burners:

$\omega=0.28 \cdot a^{-3} \cdot U^{1.5} \cdot\left(\frac{d}{a}\right)^{0.5}, \mathrm{~m} / \mathrm{s} ;$ $\omega_{n}=0.0045 \cdot U^{2} \cdot\left(\frac{d}{a}\right), \mathrm{m} / \mathrm{s}$

- for burners with forced air supply:

$\omega_{n}=0.18 \cdot a^{-3} \cdot U^{1.5} \cdot\left(\frac{d}{a}\right)^{0.5}, \mathrm{~m} / \mathrm{s}$

$\omega_{n}=0.0028 \cdot U^{2} \cdot\left(\frac{d}{a}\right), \mathrm{m} / \mathrm{s} ;$

- for burners with ceramic tunnels with a diameter $D=2.5 d$ :

$\omega=57.5 \cdot a^{-2} \cdot U \cdot\left(\frac{D}{a}\right)^{0.5}, \mathrm{~m} / \mathrm{s} ;$

$\omega=0.00775 \cdot U^{2} \cdot\left(\frac{d}{a}\right), \mathrm{m} / \mathrm{s}$.

Then from (8) and (10), taking into account (5) and (6), the expression can be obtained for determining the expansion of flame-out limits when, instead of air, recycled gas is supplied to burn gas in the burners of the first two types, and from $(12)$ - of the third type:

$$
\begin{aligned}
& \frac{\omega}{\omega_{b}}=\left(\frac{a}{a_{b}}\right)^{-3} \cdot\left(\frac{d}{d_{b}}\right)^{0.05} \cdot\left(\frac{\theta}{\theta_{b}}\right)^{1.656} \cdot R^{-1.458} ; \\
& \frac{\omega}{\omega_{b}}=\left(\frac{a}{a_{b}}\right)^{-2} \cdot\left(\frac{D}{D_{b}}\right)^{0.5} \cdot\left(\frac{\theta}{\theta_{b}}\right)^{1.656} \cdot R^{-1.458} .
\end{aligned}
$$

The oxidising agents parameters ratio that ensure the flame-out velocity for these burners is:

$R=\left(\frac{\theta}{\theta_{b}}\right)^{1.13}$.

Similarly to (9), (11), (13), taking into account (5) and (6), the ratio can be obtained of the flame backflash velocities when replacing the air with recycled gas and the condition is provided that the flame backflash velocity remains the same:

$$
\begin{aligned}
& \frac{\omega_{n}}{\omega_{n b}}=\left(\frac{d}{d_{b}}\right) \cdot\left(\frac{\theta}{\theta_{b}}\right)^{1.639} \cdot R^{-1.927} ; \\
& R=\left(\frac{\theta}{\theta_{b}}\right)^{0.85} ;
\end{aligned}
$$

Figure 6 presents a dependence of the flame backflash velocities relation on the recirculation ratio at $\omega=\omega_{b}$ and the curve $\omega / \omega_{b}=f(R)$ at $\omega_{b}=$ idem.

They are a graphical interpretation of the general solution to (16), (17) and (14), (15), (18), respectively. Their location relative to " 1 " level testifies that the use of exhaust gases recirculation, if conditions (16) and (18) are met, extends the range of straight-flow gas burners stable operation, since there is a decrease in the flame backflash velocity or an increase in the flame-out velocity. 


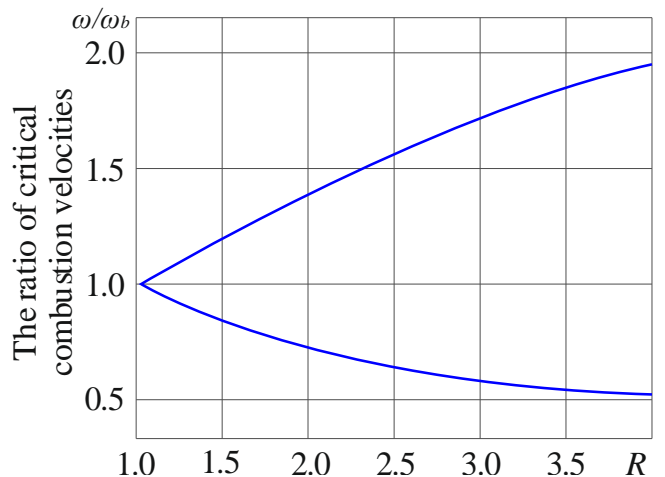

Figure 6. The ratio of the limiting velocities for sustainable combustion of gas fuel with recycled gas and air in the straight-flow burners

\section{Conclusions}

The obtained dependences make it possible to determine the combustion stability limits with a change in the oxidising agent consumption coefficient, its temperature, and the recirculation ratio. Replacement of the air with recycled gas for fuel combustion in compliance with the found their parameters ratios ensures the identical conditions of the flame stabilization. The use of recirculation when these identity conditions are met for flame backflash or flame-out, leads to an expansion of the operating range of straight-flow burners due to an increase in the flame-out velocity or a decrease in the flame backflash velocity, respectively.

\section{Acknowledgements}

Research has been performed without financial support of any grant or scientific project. The authors are grateful to the reviewers for relevant comments and recommendations on improving quality of this paper.

\section{References}

[1] Sidorkin, V.T., Tugov, A.N., Moshnikov, A.N., Vereshchetin, V.A., $\&$ Bersenev, K.G. (2016). Effect of flue gas recirculation on the technical and environmental performance of a boiler. Power Technology \& Engineering, 49(5), 354-358. https://doi.org/10.1007/s10749-016-0627-5

[2] Yu, B., Kum, S., Lee, C., \& Lee, S. (2013). Effects of exhaust gas recirculation on the thermal efficiency and combustion characteristics for premixed combustion system. Energy, 49(1), 375-383. https://doi.org/10.1016/i.energy.2012.10.057

[3] Baltasar, J., Carvalho, M.G., Coelho, P., \& Costa, V. (1997). Flue gas recirculation in a gas-fired laboratory furnace: Measurements and modelling. Fuel, 76(10), 919-929. https://doi.org/10.1016/S00162361(97)00093-8

[4] Krasnokutskaya, I.N., \& Ryzhkov, V.G. (2009). Analysis of energy saving directions in heating and thermal chamber furnaces. Metallurgy, (19), 139-144.

[5] Bondarenko, V., Tabachenko, M., \& Wachowicz, J. (2010). Possibility of production complex of sufficient gasses in Ukraine. New Techniques and Technologies in Mining, 113-119. https://doi.org/10.1201/b11329-19

[6] Bondarenko, V., Lozynskyi, V., Sai, K., \& Anikushyna, K. (2015). An overview and prospectives of practical application of the biomass gasification technology in Ukraine. New Developments in Mining Engineering 2015: Theoretical and Practical Solutions of Mineral Resources Mining, 27-32. https://doi.org/10.1201/b19901-6

[7] Sigal, I., Smikhula, A., Sigal, O., Marasin, O., \& Kernazhytska, E. (2018). Features of the influence of recirculation of combustion products on the formation of nitrogen oxides in boilers during burning natural gas. Energy Technologies \& Resource Saving, (4), 62-68. https://doi.org/10.33070/etars.4.2018.08

[8] Polishchuk, S.Z., Trotsenko, A.V., Polishchuk, A.V., \& Levchenko, O.A. (2016). The effect of lowering the temperature of flue and ventilation emissions during their disposal to change the surface concentration of air pollutants. Construction, materials science, engineering, (92), 157-162.

[9] Qian, F., Chyang, C.S., Chiou, J.B., \& Tso, J. (2011). Effect of flue gas recirculation (FGR) on $\mathrm{NO}_{x}$ emission in a pilot-scale vortexing fluidized-bed combustor. Energy \& Fuels, 25(12), 5639-5646. https://doi.org/10.1021/ef201394e

[10] Xu, L., Zhao, G., Gao, J., Du, Q., Luan, J., \& Zhao, L. (2017). Effect of flue gas recirculation on nitric oxide (NO) emissions during the coal grate-fired process. Toxicological \& Environmental Chemistry, 99(5-6),_783-794. https://doi.org/10.1080/02772248.2017.1320050

[11] Saik, P., Petlevanyi, M., Lozynskyi, V., Sai, K., \& Merzlikin, A. (2018). Innovative approach to the integrated use of energy resources of underground coal gasification. Solid State Phenomena, (277), 221-231. https://doi.org/10.4028/www.scientific.net/SSP.277.221

[12] Lozynskyi, V., Saik, P., Petlovanyi, M., Sai, K., Malanchuk, Z., \& Malanchuk, Y. (2018). Substantiation into mass and heat balance for underground coal gasification in faulting zones. Inzynieria Mineralna, 19(2), 289-300. https://doi.org/10.29227/IM-2018-02-36

[13] Sai, K., Malanchuk, Z., Petlovanyi, M., Saik, P., \& Lozynskyi, V. (2019). Research of thermodynamic conditions for gas hydrates formation from methane in the coal mines. Solid State Phenomena, (291), 155-172. https://doi.org/10.4028/www.scientific.net/SSP.291.155

[14] Gaurina-Međimurec, N., \& Novak Mavar, K. (2017). Depleted hydrocarbon reservoirs and $\mathrm{CO}_{2}$ injection wells $-\mathrm{CO}_{2}$ leakage assessment. Rudarsko Geolosko Naftni Zbornik, 32(2), 15-26. https://doi.org/10.17794/rgn.2017.2.3

[15] Lekic, A., Jukic, L., Arnaut, M., \& Macenic, M. (2019). Simulation of $\mathrm{CO}_{2}$ injection in a depleted gas reservoir: A case study for Upper Miocene sandstone, Northern Croatia. Rudarsko Geolosko Naftni Zbornik, 34(1), 139-149. https://doi.org/10.17794/rgn.2019.1.12

[16] Falshtyns'kyy, V., Dychkovs'kyy, R., Lozyns'kyy, V., \& Saik, P. (2013). Justification of the gasification channel length in underground gas generator. Annual Scientific-Technical Collection - Mining of Mineral Deposits 2013, 125-132. https://doi.org/10.1201/b16354-22

[17] Pivnyak, G., Dychkovskyi, R., Bobyliov, O., Cabana, E.C., \& Smoliński, A. (2018). Mathematical and geomechanical model in physical and chemical processes of underground coal gasification. Solid State Phenomena, (277), 1-16. https://doi.org/10.4028/www.scientific.net/ssp.277.1

[18] Tabachenko, N.M. (2001). Co-generation of heat-bearers is a XXI century technology. Ugol', (12), 47-51.

[19] Tomita, A. (2001). Catalysis of carbon-gas reactions. Catalysis Surveys from Japan, 5(1), 17-24. https://doi.org/10.1023/A:1012205714699

[20] Gorova, A., Pavlychenko, A., Kulyna, S., \& Shkremetko, O. (2012). Ecological problems of post-industrial mining areas. Geomechanical Processes During Underground Mining, 35-40. https://doi.org/10.1201/b13157-7

[21] Sarycheva, L. (2003). Using GMDH in ecological and socioeconomical monitoring problems. Systems Analysis Modelling Simulation, 43(10), 1409-1414. https://doi.org/10.1080/02329290290024925

[22] Aitkazinova, S., Soltabaeva, S., Kyrgizbaeva, G., Rysbekov, K., \& Nurpeisova, M. (2016). Methodology of assessment and prediction of critical condition of natural-technical systems. Multidisciplinary Scientific GeoConference Surveying Geology and Mining Ecology Management, (2), 3-10. https://doi.org/10.5593/sgem2016/b22/s09.001

[23] Kuz'menko, O., Petlyovanyy, M., \& Stupnik, M. (2013). The influence of fine particles of binding materials on the strength properties of hardening backfill. Annual Scientific-Technical Collection - Mining of Mineral Deposits 2013, 45-48. https://doi.org/10.1201/b16354-10

[24] Bobylev, V.P., \& Ivanov, I.I. (2015). Assessment of the effect on the emission of nitrogen oxides of the combustion mode and recirculation of flue gases. Metallurgical and Mining Industry, 1(292), 147-150.

[25] Li, J., Zhang, X., Yang, W., \& Blasiak, W. (2013). Effects of flue gas internal recirculation on $\mathrm{NO}_{\mathrm{x}}$ and $\mathrm{SO}_{\mathrm{x}}$ emissions in a co-firing boiler. International Journal of Clean Coal and Energy, 2(2), 13-21. http://doi.org/10.4236/ijcce.2013.22002

[26] Qian, F., Chyang, C.S., Yeh, J., \& Tso, J. (2013). Effect of operating conditions on $\mathrm{NO}_{\mathrm{x}}$ and co emissions in a pilot-scale vortexing fluidizedbed combustor with flue gas recirculation. Chemical Engineering \& Technology, 36(2), 268-276. https://doi.org/10.1002/ceat.201200146

[27] Rifert, V.G., \& Sereda, V.V. (2015). Condensation inside smooth horizontal tubes: Part 1. Survey of the methods of heat-exchange prediction. Thermal Science, 19(5), 1769-1789. https://doi.org/10.2298/TSCI140522036R

[28] Boscolo, M, Padoano, E, \& Tommasi, S. (2008). Identification of possible dioxin emission reduction strategies in pre-existing iron ore sinter plants. Ironmaking \& Steelmaking, 35(2), 146-152. https://doi.org/10.1179/174328107X247815 
[29] Fan, X., Yu, Z., Gan, M., Chen, X., \& Huang, Y. (2016). Flue gas recirculation in iron ore sintering process. Ironmaking \& Steelmaking, 43(6), 403-410. https://doi.org/10.1179/1743281215y.0000000029

[30] Sabdenov, K.O. (2016). Finding the concentration limits of combustion based on the analysis of diffusion-thermal instability of the flame. Methane/air/diluent mixture. Physics of Combustion and Explosion, 52(4), 24-35. https://doi.org/10.15372/FGV20160403

[31] Carlsson, H., Nordstrom, E., \& Bohlin, A. (2015). Numerical and experimental study of flame propagation and quenching of lean premixed turbulent low swirl flames at different Reynolds numbers. Combustion and Flame, 162(6), 582-2591. https://doi.org/10.1016/j.combustflame.2015.03.007

[32] Sudakov, A., Dreus, A., Ratov, B., \& Delikesheva, D. (2018). Theoretical bases of isolation technology for swallowing horizons using thermoplastic materials. News of the National Academy of Sciences of the Republic of Kazakhstan, Series of Geology and Technical Sciences, 2(428), 72-80.

[33] Birch, A.D., Brown, D.R., Cook, D.K., \& Hargrave, G.K. (1988). Flame stability in underexpanded natural gas jets. Combustion Science and Technology, 58(4-6), 267-280. https://doi.org/10.1080/00102208808923967

[34] Caetano N.R., Stapasolla, T.Z., Peng, F.B., Schneider, P.S., Pereira, F.M., \& Vielmo, H.A. (2015). Diffusion flame stability of low calorific fuels. Defect and Diffusion Forum, (362), 29-37. https://doi.org/10.4028/www.scientific.net/DDF.362.29

[35] Savas, O., \& Gollahalli, S.R. (1986). Stability of lifted laminar round gas-jet flame. Journal of Fluid Mechanics, (165), 297-318. https://doi.org/10.1017/S0022112086003105

[36] Abdulin, M.Z., \& Seryy, A.A. (2014). Research of the stability of combustion in a stream-on-line system while limiting the range of fuel jets. Energetics: Economics, Technology, Ecology, (3), 22-28. https://doi.org/10.20535/1813-5420.3.2014.122097

[37] Yinli, X., Zhibo, C., \& Changwu, W. (2018). Flame stability limits of premixed low-swirl combustion. Advances in Mechanical Engineering, 10(9), 1-11. https://doi.org/10.1177/1687814018790878

[38] Sirignano, W. (2014). Driving mechanisms for combustion instability. Combustion Science and Technology, 187(1-2), 162-205. https://doi.org/10.1080/00102202.2014.973801

[39] Zel'dovich, Ya.B., Barenblatt, G.I., Librovich, V.B., \& Makhviladze, G.M (1980). Mathematical theory of combustion and explosion. Moscow, Russia: Russia Science. https://doi.org/10.33271/mining13.02.103

[40] Rani, V.K., \& Rani, S.L. (2018). Development of a comprehensive flame transfer function and its application to predict combustion instabilities in a dump combustor. Combustion Science and Technology, 190(8), 1313-1353. https://doi.org/10.1080/00102202.2018.1440215

[41] Silva, C.V., Deon, D.L., Centeno, F.R., França, F.H., \& Pereira, F.M. (2018). Assessment of combustion models for numerical simulations of a turbulent non-premixed natural gas flame inside a cylindrical chamber. Combustion Science and Technology, 190(9), 1528-1556. https://doi.org/10.1080/00102202.2018.1456430

[42] Schiro, F., \& Stoppato, F. (2019). Experimental investigation of emissions and flame stability for steel and metal fiber cylindrical premixed burners. Combustion Science and Technology, 191(3), 453-471. https://doi.org/10.1080/00102202.2018.1500556

[43] Isserlin, A.S. (1987). Fundamentals of gas fuel combustion. Leningrad, Russian Federation: Subsoil.

[44] Mednikov, Yu.P., Dymov, G.D., \& Reykhert, K.N. (1982). Operation of industrial furnaces and gas-fired dryers. Leningrad, Russian Federation: Subsoil.

\section{Дослідження меж стабілізації полум'я газових пальників при рециркуляції димових газів}

\section{I. Іванов, С. Поліщук, І. Голякова, С. Кушнір}

Мета. Визначення впливу рециркуляції димових газів на межі стабілізації полум'я газових пальників на основі експериментальних промислових досліджень.

Методика. Дослідження проводилися на кільцевій нагрівальної печі діаметром 30 м колесопрокатного цеху ВАТ “Інтерпайп НТЗ”. Піч для нагріву заготовок до $625 \pm 25^{\circ} \mathrm{C}$ і їх ізотермічної витримки має 5 зон 3 регульованою подачею природного газу та методичну. Для підвищення ефективності теплової роботи піч була оснащена системою зовнішньої рециркуляції відпрацьованих газів. При оцінці форсувальної здатності пальників після їх розпалювання поступово підвищували витрату газу і рециркуляту в заданому співвідношенні і визначали витрата газу в момент зриву факела, який фіксувався візуально.

Результати. Виділено фактори, що впливають на стійкість режимів роботи пальників при подачі в зону горіння відпрацьованих димових газів шляхом комплексного. Показано, що найбільш раціональним для аналізу впливу рециркуляції на стійкість горіння газу є використання критеріальних емпіричних моделей, що враховують комплекс фізико-хімічних характеристик реагентів, параметрів режиму спалювання, газодинамічних та конструктивних особливостей пальника. Отримано критеріальну модель зриву дифузійного факела в комбінованих пальниках типу “труба в трубі” при спалюванні газового палива в середовищі рециркулюючих димових газів $з$ температурою $140-200^{\circ} \mathrm{C}$ і вмістом кисню в них 15.4-19.6\%. Встановлено залежності для оцінки зсуву кордонів стійкості горіння при зміні коефіцієнта витрати окиснювача, його температури і кратності рециркуляції.

Наукова новизна. Отримані нові розрахункові моделі для оцінки меж стабілізації полум'я прямоточних газових пальників при рециркуляції димових газів і знайдені співвідношення кратності рециркуляції та температур окиснювачів, що забезпечують умови ідентичності їх роботи по зриву факела і проскакуванню полум'я при заміні повітря рециркулятом на спалювання палива.

Практична значимість. Результати дозволяють зробити обгрунтований вибір пальників і режимних параметрів спалювання, що забезпечують безпечну експлуатацію агрегату при рециркуляції димових газів.

Ключові слова: спалювання, паливо, рециркуляція, стійкість, зрив факела, проскакування полум'я, пальник, модель

\section{Исследование границ стабилизации пламени газовых горелок при рециркуляции дымовых газов}

\section{И. Иванов, С. Полищук, И. Голякова, Е. Кушнир}

Цель. Определение влияния рециркуляции дымовых газов на границы стабилизации пламени газовых горелок на основе экспериментальных промышленных исследований.

Методика. Исследования проводились на кольцевой нагревательной печи диаметром 30 м колесопрокатного цеха ОАО “Интерпайп НТ3”. Печь для нагрева заготовок до $625 \pm 25^{\circ} \mathrm{C}$ и их изотермической выдержки имеет 5 зон с регулируемой подачей природного газа и методическую. Для повышения эффективности тепловой работы печь была оснащена системой внешней рециркуляции отработавших газов. При оценке форсированной способности горелок после их разжигания постепенно повышали расход газа и рециркулята в заданном соотношении и определяли расход газа в момент срыва факела, который фиксировался визуально.

Результаты. Выделены факторы, влияющие на устойчивость режимов работы горелок при подаче в зону горения отработавших дымовых газов. Показано, что наиболее рациональным для анализа влияния рециркуляции на устойчивость горения газа является использование критериальных эмпирических моделей, учитывающих комплекс физико-химических характеристик реагентов, параметров режима сжигания, газодинамических и конструктивных особенностей горелки. Получена критериальная модель срыва диффузионного факела в комбинированных горелках типа “труба в трубе” при сжигании газового топлива в среде рециркулирующих 
дымовых газов с температурой $140-200^{\circ} \mathrm{C}$ и содержанием кислорода в них 15.4-19.6\%. Установлены зависимости для оценки смещения границ устойчивости горения при изменении коэффициента расхода окислителя, его температуры и кратности рециркуляции.

Научная новизна. Получены новые расчетные модели для оценки границ стабилизации пламени прямоточных газовых горелок при рециркуляции дымовых газов и найдены соотношения кратности рециркуляции и температур окислителей, обеспечивающие условия идентичности их работы по срыву факела и проскоку пламени при замене воздуха рециркулятом на сжигание топлива.

Практическая значимость. Результаты позволяют сделать обоснованный выбор горелочных устройств и режимных параметров сжигания, обеспечивающих безопасную эксплуатацию агрегата при рециркуляции дымовых газов.

Ключевые слова: сжигание, топливо, рециркулячия, устойчивость, срыв факела, проскок пламени, горелка, модель

\section{Article info}

Received: 3 June 2019

Accepted: 17 January 2020

Available online: 3 February 2020 